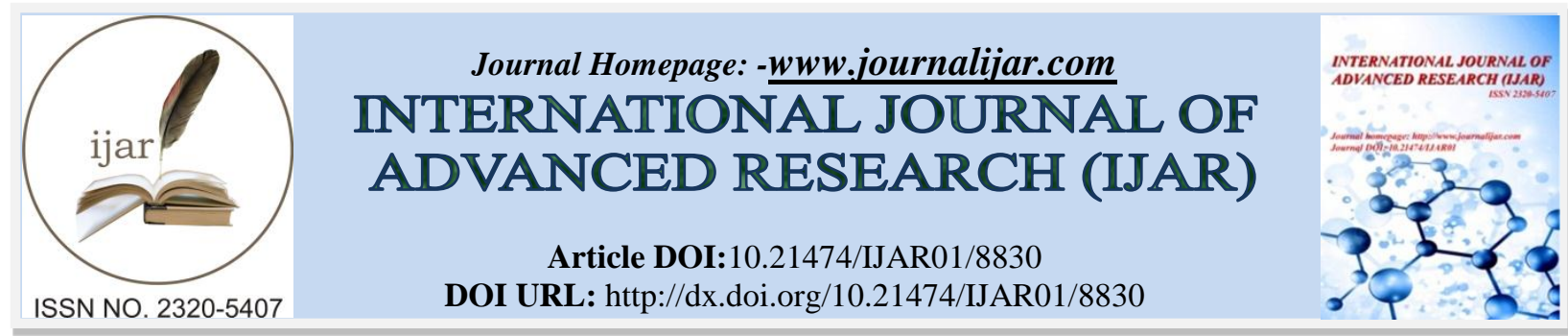

RESEARCH ARTICLE

\title{
AWARENESS OF ORGAN DONATION IN NEWLY ADMITTED STUDENTS OF MEDICAL COLLEGE: A CASE CONTROL STUDY IN WESTERN MAHARASHTRA
}

Anjum Sayyed ${ }^{1}$ and Dr. Shilpa A Pratinidhi ${ }^{2}$.

1. Tutor, Department of Biochemistry, MIMER Medical College Talegaon (D) Pune.

2. Professor\& Head, Department of Biochemistry, MIMER Medical College, Talegaon Dabhade Pune, Maharashtra- India.

\section{Manuscript Info}

\section{Manuscript History}

Received: 06 February 2019

Final Accepted: 08 March 2019

Published: April 2019

Key words:-

Organ donation, Knowledge, Awareness,

$1^{\text {st }}$ MBBS students.

\begin{abstract}
Introduction: Organ transplantation is the process of replacing diseased organs, parts of organs or tissues by healthy organs or tissues. The only way to increase organ donations is to educate the health care professionals and public about the importance of becoming an organ donor. One of the best ways is to educate the youngsters in the medical field.

Aims: This study aims to determine the knowledge and awareness of $1^{\text {st }}$ MBBS students regarding organ donation.

Material \& Methods: Cross sectional questionnaire based study was conducted in Medical College of Western Maharashtra. Total 50 students, consisting both male (23) and female (27) students participated in the study. The aim was achieved by opting pre and post written test by predefined questionnaire, so as to check knowledge gained by the newly admitted $1^{\text {st }}$ MBBS students of MIMER Medical College before and after showing a short film "Hello Jindagi", followed by interactive discussion based on the organ donation. Data was analyzed in Microsoft Excel.

Results \& Conclusion: The results showed that knowledge gained after showing film was raised from $81 \%$ to $96 \%$. So over all $15 \%$ gain in the knowledge was observed. "Paired t test" indicate statistically significant difference $(\mathrm{P}<0.049)$ between pre and post-test. The results of the study revealed that there exists a knowledge gap and lack of awareness among the medical students regarding organ donation and there is an urgent need for addressing this knowledge gap which will help in improving the organ donation rate in our country. By giving right knowledge and orientation medicos can be become future organ donors who can then easily motivate their patients to follow the path.
\end{abstract}

Copy Right, IJAR, 2019,. All rights reserved.

\section{Introduction:-}

Organ donation programs are at a very primordial stage in India and are almost negligible in Maharashtra (Tamuli, Sarmah, \& Saikia, 2019) Organ donation stands above everything because it saves the life of the person and make him enjoy other benefits (Ilango, Nandhini, Manikandan, \& Sembulingam, 2014). Organ donation is defined as 
when a person allows an organ of theirs to be removed, legally, either by consent while the donor is alive or after death with the assent of the next of kin for the purpose of transplantation as a treatment (Tamuli et al., 2019) (Bathija, Ananthesh, \& Bant, 2017). Though transplantation has been in practice in India for more than three decades, it has been grossly inadequate in terms of actual numbers, due to a shortage of resources and organs. According to a survey in India every year about 5 lakh people die because of non-availability of organs and 1.5 lakh people await a kidney transplant but only 5,000 get among them. Organ replacement remains only a dream for the vast majority of these patients. Every year thousands of individuals wait for organ transplantation (Sree T, Sucharitha, Ravi, Siriki, Rajeshwara, Rao Dugyala, Mullai, Priyadarshini, Kaavya, 2013).

To streamline organ donation and transplantation activities the legislation called Transplantation of Human Organ Act (THO) was passed in India in 1999, Koushal, Rai, \& Gupta, 2014). Andhra Pradesh and Telangana state government developed cadaver transplantation scheme, Jeevandan to bring awareness in public (Tamuli et al., 2019).

In spite of all these efforts, awareness of the organ donation is still in dearth. The reasons for this pathetic scenario may be the ignorance of common public about the importance, procedures, benefits and legal issues of organ donation (Ilango et al., 2014). A study stated that even medical fraternity was lacking clarity with regards to the rules and procedures related to organ transplantation (Jothula \& Sreeharshika, 2018). This emphasizes that providing adequate knowledge regarding organ donation in the community is the need of the hour. The best way to start this is to promote the awareness of the college students, especially those in the medical field, towards organ donation because they will be the most suitable persons to carry the message to the community. As future doctors, medical students can take up the role of promoting organ donation as they are the most critical link in the organ procurement process, by educating and motivating the public to pledge their organs for donation (Jothula \& Sreeharshika, 2018). Therefore, assessing medical student's knowledge and awareness regarding organ donation is very important for the future organ supply. With this background this study was undertaken with the objective of assessing the awareness of the newly admitted medical students towards organ donation in a private medical college of Maharashtra state.

\section{Materials and Methods:-}

A cross sectional questionnaire based study was under taken in the newly admitted fifty, $1^{\text {st }}$ MBBS students of Medical College. A pretested, semi-structured questionnaire was standardized by conducting pilot study. The questionnaire consists of the information about demographic data like age, gender and religion and fifteen questions were asked to assess knowledge and awareness. Both open and closed end questions were included in this part. Score was allotted to each question based on the response. Subjects who secured $50 \%$ or more were considered as having adequate knowledge and those with less than $50 \%$ were considered as having inadequate knowledge towards organ donation.

The questionnaire was prepared in English language. Questionnaire was administered to the newly admitted $1^{\text {st }}$ MBBS students. Pre-test was conducted and after that the filled questionnaire were collected back. The film "HELLO ZINDGI" was shown on organ donation so as to enhance knowledge and create awareness. The film had covered most of the ethical aspect of organ donation. Then it was followed by lecture on organ donation. All questions about organ and body donation were clarified. Followed by film and lecture an interactive discussion was carried out. Any queries regarding the topic of organ and body donation (whether general or related to organ donation) or questions asked by student were cleared. Then post-test was conducted and the filled questionnaire was collected back. Confidentiality regarding the participant response for the questions was ensured. Then knowledge gain in pre and post-test was compared.

The inclusion criterion for the study participants were belongs to age group between 18 to 21 years and exclusion criterion was those who refused to give consent. Only those consenting to participate were involved in the study. The respondents were assured that their confidentiality would be maintained and ethical principles would be followed.

\section{Statistical Analysis:}

Results were described in Mean \pm SD and student "Paired t test" was used for final analysis of pre and post test score. Data was analyzed in Microsoft Excel. 


\section{Results:-}

Table 1:- Distribution of study participants according to their age, gender and religion

\begin{tabular}{|l|l|l|}
\hline Sr No. & Variable $(\mathbf{n}=\mathbf{5 0})$ & Frequency $\mathbf{( \% )}$ \\
\hline $\mathbf{1 .}$ & Age in years & \\
\hline & Male & $18.10 \pm 0.95$ \\
\hline & Female & $18.08 \pm 1.049$ \\
\hline & Mean Age \pm SD $=\mathbf{1 8 . 1 8} \pm \mathbf{1 . 9 9}$ & \\
\hline $\mathbf{2 .}$ & Sex & $23(46 \%)$ \\
\hline & Male & $27(54 \%)$ \\
\hline & Female & \\
\hline $\mathbf{3 .}$ & Religion & $47(94 \%)$ \\
\hline & Hindu & $03(6 \%)$ \\
\hline & Muslim & \\
\hline
\end{tabular}

Table 2: Assessment of knowledge gain by study participants on organ donation

\begin{tabular}{|c|c|c|c|}
\hline \multirow[t]{2}{*}{$\begin{array}{l}\text { Sr } \\
\text { No. }\end{array}$} & \multirow[t]{2}{*}{ Questions } & \multicolumn{2}{|c|}{$\begin{array}{c}\text { Number of students answered } \\
\text { correctly } \\
\mathbf{N}=\mathbf{5 0}(\mathbf{1 0 0} \%)\end{array}$} \\
\hline & & Pre test & Post test \\
\hline 1. & $\begin{array}{l}\text { If you see an accident on the road what will you do? } \\
\text { i) Take the patient immediately to the hospital } \\
\text { i) Keep watching the situation } \\
\text { ii) Call their relatives } \\
\text { iii) None of these }\end{array}$ & $\begin{array}{c}49 \\
(98 \%)\end{array}$ & $\begin{array}{c}50 \\
(100 \%)\end{array}$ \\
\hline 2. & $\begin{array}{l}\text { Suppose the patient was brain dead? } \\
\text { i) Will you convenience patient to donate the organ } \\
\text { ii) Will you protest patient not to donate the organ } \\
\text { iii) Not to do anything } \\
\text { iv) Will call police }\end{array}$ & $\begin{array}{c}44 \\
(88 \%)\end{array}$ & $\begin{array}{c}50 \\
(100 \%)\end{array}$ \\
\hline 3. & $\begin{array}{l}\text { What idea do you have about organ donation? } \\
\text { i) It is an act of giving organ to needy person } \\
\text { ii) It is an generous act } \\
\text { iii) Donor should be alive or dead } \\
\text { iv) All of the above }\end{array}$ & $\begin{array}{c}49 \\
(98 \%)\end{array}$ & $50(100 \%)$ \\
\hline 4. & $\begin{array}{l}\text { Who can donate the organs } \\
\begin{array}{ll}\text { i) Alive person } & \text { ii) Dead person } \\
\text { ii) Brain dead person } & \text { iv) All }\end{array}\end{array}$ & $\begin{array}{c}47 \\
(94 \%)\end{array}$ & $\begin{array}{c}50 \\
(100 \%)\end{array}$ \\
\hline 5. & $\begin{array}{l}\text { If yes, once patient expired in how much time organ can be donated? } \\
\begin{array}{ll}\text { i) within } 6 \text { hour } & \text { ii) } 72 \text { within hour } \\
\text { iii) within } 24 \text { hour } & \text { iv) within } 4\end{array}\end{array}$ & $\begin{array}{c}11 \\
(22 \%)\end{array}$ & $50(100 \%)$ \\
\hline 6. & $\begin{array}{l}\text { Which are the organs that can be donated? } \\
\text { i) Kidney ii) liver iii) eye iv) brain }\end{array}$ & $\begin{array}{c}50 \\
(100 \%) \\
\end{array}$ & $\begin{array}{c}49 \\
(98 \%) \\
\end{array}$ \\
\hline 7. & $\begin{array}{l}\text { In which conditions organ cannot be donated? } \\
\text { i) Cancer \& Systemic infection } \\
\text { ii) Healthy organ } \\
\text { iii) All of the above } \\
\text { iv) None of the above }\end{array}$ & $49(98 \%)$ & $\begin{array}{c}49 \\
(98 \%)\end{array}$ \\
\hline 8. & $\begin{array}{l}\text { Organ donation is ethical or unethical practice? } \\
\begin{array}{lll}\text { i) Ethical } & \text { ii) Unethical }\end{array}\end{array}$ & $50(100 \%)$ & $50(100 \%)$ \\
\hline 9. & $\begin{array}{l}\text { What is informed consent } \\
\text { i) Voluntariness ii) Agreement to do something } \\
\text { iii) Both i \& ii options are correct } \\
\text { iv) Unwillingness }\end{array}$ & $49(98 \%)$ & $49(98 \%)$ \\
\hline 10. & Have you donated your organ? (Y/N) & $0(0 \%)$ & $0(0 \%)$ \\
\hline
\end{tabular}




\begin{tabular}{|c|c|c|c|}
\hline 11. & If no, would you like to donate? (Y/N) & $\begin{array}{l}45 \quad(90 \%) \\
\text { willing } \\
\text { donate, } \\
1(2 \%) \mathrm{NA}, \\
4(8 \%) \\
\text { Not willing } \\
\end{array}$ & $\begin{array}{lr}48 & (96 \%) \\
\text { willing } & \text { to } \\
\text { donate, } & \\
2(4 \%) & \text { Not } \\
\text { willing } & \end{array}$ \\
\hline 12. & Does your religion support donation? (Y/N) & $\begin{array}{l}41(82 \%) \text { yes } \\
7(14 \%) \text { NO } \\
2(4 \%) \text { NA }\end{array}$ & $\begin{array}{l}46(92 \%) \text { Yes } \\
3(6 \%) \text { NO } \\
1(2 \%) \text { NA }\end{array}$ \\
\hline 13. & $\begin{array}{l}\text { At what age can someone become a donor? } \\
\begin{array}{llll}\text { i) } 15 & \text { ii) } 18 \text { iii) } 90 \text { iv) any age }\end{array}\end{array}$ & $16(32 \%)$ & $42(84 \%)$ \\
\hline 14. & Can whole body donor's body be cremated after organ donation $(\mathrm{Y} / \mathrm{N})$ ? & $26(52 \%)$ & $40(80 \%)$ \\
\hline 15. & $\begin{array}{l}\text { What take home message would you like to give to the society about } \\
\text { organ donation? Is it Good/ bad practice? (Y/N) }\end{array}$ & $\begin{array}{c}42(84 \%) \\
\text { Good practice } \\
8(16 \%) \text { bad } \\
\text { practice }\end{array}$ & $\begin{array}{c}48(96 \%) \\
\text { Good practice } \\
2(4 \%) \text { bad } \\
\text { practice }\end{array}$ \\
\hline
\end{tabular}

Abbreviations: NA- Not attempted, Y- Yes and N - No

Table 3: Awareness about organ donation with respect to willingness

\begin{tabular}{|l|c|c|c|c|}
\hline $\begin{array}{l}\text { If no, would you like to } \\
\text { donate? (Y/N) }\end{array}$ & $\begin{array}{c}\text { Pre -test Score } \\
\text { N=50 (number of students } \\
\text { answered) }\end{array}$ & $\begin{array}{c}\mathbf{5 0}(\mathbf{1 0 0 \%}) \\
\begin{array}{c}\text { Post -test Score } \\
\text { N=50 (number of } \\
\text { students answered) }\end{array}\end{array}$ & $\begin{array}{c}\mathbf{5 0} \\
\mathbf{( 1 0 0 \%}\end{array}$ \\
\hline Not Attempted & 1 & $(2 \%)$ & 0 & $(0 \%)$ \\
\hline Willing to donate & 45 & $(90 \%)$ & 48 & $(96 \%)$ \\
\hline Not willing to donate & 4 & $(8 \%)$ & 2 & $(4 \%)$ \\
\hline
\end{tabular}

Table 4: Awareness about organ donation with respect to religion

\begin{tabular}{|l|c|c|c|c|}
\hline $\begin{array}{l}\text { Does your religion Support } \\
\text { donation? }\end{array}$ & $\begin{array}{c}\text { Pre-test Score } \\
\text { N=50 (number of students } \\
\text { answered) }\end{array}$ & $\begin{array}{c}\mathbf{5 0} \\
\mathbf{( 1 0 0 \% )}\end{array}$ & $\begin{array}{c}\text { Post-test Score } \\
\text { N=50 (number of students } \\
\text { answered) }\end{array}$ & $\begin{array}{c}\mathbf{5 0} \\
\mathbf{( 1 0 0 \% )}\end{array}$ \\
\hline Not Attempted & 2 & $4 \%$ & 1 & $2 \%$ \\
\hline Yes & 41 & $82 \%$ & 46 & $92 \%$ \\
\hline NO & 7 & $14 \%$ & 3 & $6 \%$ \\
\hline
\end{tabular}

\section{Results:-}

Among 50 participants, $23(46 \%)$ were male and $27(54 \%)$ were female $1^{\text {st }}$ MBBS students. Their mean age was $18.18 \pm 1.99$ years and among them $94 \%$ were Hindus, $6 \%$ were Muslim (Table 1). Awareness about organ donation was assessed by testing knowledge of study participants as shown in the Table 1.The study participants had adequate knowledge before pre-test (score 700/569 i.e 81\%) and after film and discussion post test score becomes 700/671 i. e $96 \%$. The two-tailed "paired t test" indicate statistically significant difference $(\mathrm{P}<0.049)$ between pre and post-test. So, in the present study overall $15 \%$ gain in the knowledge was seen after showing film and interactive discussion.

When asked about opinion on brain death accident, pre-test score was $44(88 \%)$ participants answered correctly and in the post-test this score raised to $50(100 \%)$ students. In the post-test all students answered rightly. However in the pre-test $49(98 \%)$ students had correct idea about organ donation, while in the post test it becomes 50 (100\%). Not much difference was observed in the pre and post-test. 47 (94\%) student had adequate knowledge about who can donate in the pre-test and post-test this score raised to $50(100 \%)$. Further in the pre-test $11(22 \%)$ students know about once patient get expired within how much time organ can be donated and in the post-test all students knew the correct time for organ donation after patients get expired. Most of the study participants knew what all organs can be donated and in which condition it cannot be donated. All students knew that organ donation is ethical practice. Regarding the informed consent in both pre and post-test 49 (98\%) participants knew about consent. None of the student had donated organ previously (Table. 2). 
In the pre-test $45(90 \%)$ of the study participants were willing to donate their organ, $4(8 \%)$ were not willing to donate the organ. A small number of participants $1(2 \%)$ did not attempt the question. Whereas 48 (96\%) study participants were willing to donate their organ and $2(4 \%)$ were not willing to donate the organ in the post-test (Table.3). The reason for being not donating organ may be religion barrier. In the pre-test 41(82\%) participants religions allow to donate the organ. 7 (14\%) participant's religion did not want organ donation. Small 2 (4\%) participants did not attempt the question. However in the post-test 46(92\%) participant's religion allow to donate the organ. Only $3(6 \%)$ participant's religion said no to organ donation (Table.4). So this predicts that religious belief played minor role for negative attitude for organ donation. $16(32 \%)$ and $42(94 \%)$ study participants knew about age of donor in the pre-test and post-test respectively (Table. 2). In the pre-test $26(52 \%)$ participants knew that whole donor's body will not be available for cremation after organ donation, while in the post test this score raises to $40(80 \%)$ (Table. 2$)$.

Lastly, when students were asked about organ donation is it good practice or bad both in the pre-test and post-test results revealed $42(84 \%)$ and $48(96 \%)$ respectively. On the contrary bad practice were reported by $8(16 \%)$ and 2 (4\%) students in the pre-test and post- test respectively (Table. 2).

\section{Discussion:-}

Organ transplantation is one of the greatest scientific advances and remains one of the most challenging and complex field of modern medicine. The World Health Organization (WHO) defines organ donation as the gift of an individual's body parts after their demise for transplantation (Ganta, Pamarthi, \& K, 2018). The present study provides several important insights into the knowledge and awareness of organ donation among newly admitted $1^{\text {st }}$ MBBS students of Medical College. In this study, male and female subjects constitute 23 (46\%) and 27 (54\%) respectively, While most of them were Hindus 47(94\%) and only 3(6\%) were Muslims.

In the present study, all of the $1^{\text {st }}$ MBBS students had adequate knowledge about organ donation (adequate means more than $50 \%$ knowledge). It is similar to study done by Kishore Jothula et al (Jothula \& Sreeharshika, 2018). All the participants had heard about organ donation. During discussion when asked orally what are main sources of information about organ donation. The participants answered internet, social network and television. These findings highlight the role of media, social network in bringing awareness about organ donation.

When asked about what will do when you see an accident on the road all of them answered they will take patient immediately to the hospital. All study participants had adequate idea about organ donation. 47 (94\%) student had adequate knowledge about who can donate in the pre-test and post-test this score becomes 50 (100\%). Further in the pre-test 11(22\%) students know about once patient get expired within how much time organ can be donated and in the post test all students knew the correct time for organ donation once patients get expired. Most of the study participants knew what all organs can be donated and in which condition it cannot be donated. However only $35 \%$ of the study participants had identified all the organs that can be donated by Jothula KY et al study (Jothula \& Sreeharshika, 2018), whereas it was only 26\% according to Karini et al (Deepthi Karini, Sunitha S, 2015). While Payghan et al reported that most of participants $(86.76 \%$ ) knew that organ donation is legal in India (Payghan, Kadam, \& Furmeen, 2014). However in our study all students 50(100\%) knew that organ donation is ethical practice. About the informed consent in both pre and post-test 49 (98\%) participants knew about consent. Jothula KY et al mention only $53.7 \%$ participants were aware that consent is required for donating organs (Jothula \& Sreeharshika, 2018).

None of the students had donated organ previously. Present study shows, in the pre-test 45 (90\%) participants were willing to donate their organs, $4(8 \%)$ participants not willing to donate and a small percentage 1 (2\%) of the respondents was not attempted the question. While in the post-test after film and interactive discussion 48 (96\%) participants were willing to donate their organs and $2(4 \%)$ of the respondents was not willing to donate their organs (Table.3). The reason for being not donating could be religion barrier. Though all the religions are not against organ donation there seems to be presence of myths and misconceptions even among medical students. In the pre-test $41(82 \%)$ participants religion allow to donate the organ. $7(14 \%)$ participant's religion say no to organ donation. Only 2 (4\%) participants did not attempt the question. However in the post-test 46 (92\%) participant's religion allow to donate the organs. Only 3(6\%) participant's religion says no to organ donation (Table. 4). This sudden change of attitude towards no to yes could be possible because of awareness. As per Jothula KY et al (2108) observation most (78.7\%) of the study subjects knew that all religions tend to support to organ donation (Jothula \& Sreeharshika, 2018). 
In this study, in the pre-test only $16(32 \%)$ new at what age organ can be donated, while after film, discussion, posttest $40(80 \%)$ study participants came to know exact age for organ donation (Table. 2). Jothula KY et al reported (45.6\%) of interns knew that there is age limit for organ donation (Jothula \& Sreeharshika, 2018) which is similar to the findings of Agarwal (43\%), Karini et al (47.2\%) and in contrast to Sucharitha et al reported it as only $19.2 \%$ (Agarwal, 2015), (Deepthi Karini, Sunitha S, 2015), (Sree T, Sucharitha, Ravi, 2013).

It was overwhelming that majority of the participants had positive attitude and are willing to donate organs which is similar to the findings of Payghan et al (87\%) and Vinay et al (90\%) (Payghan et al., 2014),(KV, Beena, KS, \& Praveen, 2016). The present study found that there is a significant association between knowledge acquired regarding organ donation and willingness to donate organs. Similar finding was observed in Pakistan study done by Ali et al (Ali, Qureshi, Jilani, \& Zehra, 2013). Other study found that the most common reason for not being an organ donor was found to be fear of organs misuse (Sree T, Sucharitha, Ravi, Siriki, Rajeshwara, Rao Dugyala, Mullai, Priyadarshini, Kaavya, 2013). Vinay et al study reported that majority (98\%) of the study subjects would like to motivate others for organ donation (KV et al., 2016). These findings reflect the importance of bringing awareness about organ donation among medical students. Adithyan et al observed that $91.2 \%$ of the subjects felt the need for revision of medical curriculum on organ donation (Adithyan, Mariappan, \& Nayana, 2017). The present study showed that only $81 \%$ knows about organ donation before conduction of test indicating the need to sensitize the medical students about organ donation.

In the pre-test only $26(52 \%)$ participants knew that if whole body is donated, body will not be available for cremation after organ donation, while in the post test this score becomes 40 (80\%) (Table.2). On request for performing religious rituals, only nail and hair can be provided. According to Jothula KY et al majority (88.75\%) of the participants knew that donor body will not be cremated after organ donation (Jothula \& Sreeharshika, 2018).

Finally, students were asked about organ donation is it good practice or bad both in the pre-test and post-test results revealed 42 (84\%) and 48 (96\%) respectively. On the other hand bad practice was reported by students 8 (16\%) in the pre-test and $2(4 \%)$ students in the post-test. So, awareness had brought the change about mentioning of bad practice from $8(16 \%)$ in the pre-test to $2(4 \%)$ students in the post- test.

In India, Transplant of Human Organs Act (THOA) 1994 amended in 2011 regulates the removal, storage and transplantation of human organs/tissues for therapeutic purposes and prevents the commercial dealings of human organs. So there is an urgent need to address this issue among medicos. It was shocking to know that no one of the study subjects had heard about Jeevandan scheme (Telangana state government cadaver transplantation scheme) when asked orally. According to Adithyan et al $88.7 \%$ of final year medical students in Kerala knew about their state governments Mritasanjeevani (Adithyan et al., 2017).

Most of the study participants had adequate knowledge and positive attitude before pre-test (score 700/569 i. e 81\%) but after film and discussion, post test score rises to 700/671 i.e $96 \%$ of the study participants. So overall post-test $15 \%$ gain in the knowledge was observed after showing film and discussion. This indicates the need to sensitise the youngsters of medical field regarding organ donation and the acts related to it. Healthcare professionals and medical students can serve as role models for patients and as well as for public and achieve greater success for organ procurement for transplantation. The main strength of this study being inclusion of the freshly admitted $1^{\text {st }}$ MBBS students, so that they can get an opportunity to improve their knowledge about organ donation and propagate same to the community.

\section{Conclusion:-}

To the best of our knowledge this was the first kind of study carried out on organ donation in this region. There is a positive attitude of medical students towards organ donation, but there is lack of sufficient knowledge on the topic. As the budding doctors are the future hopes of our country, enlightening and motivating them about organ donation through camps, workshops, discussion with teachers, friends and family and media will definitely have a bigger impact on the entire nation in the long run to bring awareness on mass scale. We intend to carry out community based studies on the larger population.

\section{Limitation:}

The study can not be generalized due to the small sample size and also it was done in a specific population (Medical students). 


\section{Acknowledgement:-}

The authors were grateful to all $1^{\text {st }}$ MBBS students for their kind cooperation in data collection and active involvement in the pre and post-test conduction. Authors are also thankful to the management of our college for promoting active research.

\section{Declarations}

\section{Funding:}

No funding sources

\section{Conflict of interest:}

None declared

\section{References:-}

1. Adithyan, G. S., Mariappan, M., \& Nayana, K. B. (2017). A Study on Knowledge and Attitude about Organ Donation among Medical Students in Kerala. Indian J Transplant, 11, 133-137. https://doi.org/10.4103/ijot.ijot

2. Agarwal, S. (2015). Are Medical Students Having Enough Knowledge about Organ Donation. IOSR Journal of Dental and Medical Sciences, 14(7), 29-34. https://doi.org/10.9790/0853-14752934.

3. Ali, N. F., Qureshi, A., Jilani, B. N., \& Zehra, N. (2013). Knowledge and ethical perception regarding organ donation among medical students. BMC Medical Ethics, 14, 38.

4. Bathija, G. V, Ananthesh, B. G., \& Bant, D. D. (2017). Study to Assess Knowledge and Attitude towards Organ Donation among Interns and Post Graduates of a Medical College in Karnataka, India. National Journal of Community Medicine, 8(5), 236-240.

5. Deepthi Karini, Sunitha S, D. M. B. (2015). Perceptions of Medical students in a government medical college towards organ donation. $\mathrm{J}$ of Evidence Based Med \&Healthcare, 2(44), 7998-8005. https://doi.org/10.18410/jebmh/2015/1075.

6. Ganta, S. R., Pamarthi, K., \& K, L. P. K. (2018). Knowledge and attitude regarding organ donation and transplantation among undergraduate medical students in north coastal Andhra Pradesh. International Journal of Community Medicine and Public Health, 5(3), 1064-1068.

7. Government of India. Transplantation of Human Organs Act, 1994. Central Act 42 of 1994.

8. Ilango, S., Nandhini, M. M. U., Manikandan, S., \& Sembulingam, P. (2014). Awareness of Organ Donation among Fresh Students in Medical. Valley International Journals, 1(6), 274-283.

9. Jothula, K. Y., \& Sreeharshika, D. (2018). Study to assess knowledge, attitude and practice regarding organ donation among interns of a medical college in Telangana, India. International Journal of Community Medicine and Public Health, 5(4), 1339-1345.

10. Koushal, V., Rai, A. K., \& Gupta, A. K. (2014). Organ Donation Promotion in India: A Critical Analysis. International Journal of Health Sciences \& Research, 4(August), 226-228.

11. KV, V., Beena, N., KS, S., \& Praveen, S. (2016). Changes in knowledge and attitude among medical students towards organ donation and transplantation. International Journal of Anatomy and Research, 4(3), 2873-2877. https://doi.org/10.16965/ijar.2016.259

12. Payghan, B. S., Kadam, S. S., \& Furmeen, S. (2014). Awareness and perception among medical students. Journal of Pharmaceutical and Scientific Innovation Research, 3(4), 379-381. https://doi.org/10.7897/22774572.034178.

13. Sree T, Sucharitha, Ravi, Siriki, Rajeshwara, Rao Dugyala, Mullai, Priyadarshini, Kaavya, R. (2013). Organ Donation: Awareness, attitudes and beliefs among undergraduate medical students in South India Introduction: National Journal of Research in Community Medicine, 2(2), 83-88.

14. Tamuli, R. P., Sarmah, S., \& Saikia, B. (2019). Organ donation - "attitude and awareness among undergraduates and postgraduates of North - East India," 130-136. https://doi.org/10.4103/jfmpc.jfmpc. 